\title{
Historia zastosowania promieniowania protonowego w radioterapii
}

\section{History of using proton irradiation in radiotherapy}

\author{
Marika Musielak ${ }^{1}$ \\ ${ }^{1}$ Katedra i Zaklad Elektroradiologii, Uniwersytet Medyczny im. Karola Marcinkowskiego w Poznaniu
}

\begin{abstract}
Abstrakt
Historia terapii protonowej rozpoczęła się w 1946 roku kiedy Robert Wilson opublikował artykuł, w którym zaproponował wykorzystanie akceleratorów formujących wiązkę protonową do leczenia głęboko zlokalizowanych guzów. W konwencjonalnej radioterapii wykorzystywane jest promieniowanie fotonowe. Opisując przewagę promieniowania protonowego nad fotonowym należy zwrócić uwagę na jego aspekty fizyczne m.in. rozkład głębokościowy dawki. Rozkład dawki w ośrodku maleje wykładniczo dla fotonów, natomiast dla protonów rozkład głębokości dawki ma charakterystyczny kształt, zwany pikiem Bragga. Celem pracy jest przedstawienie historii terapii protonowej rozpoczynając od odkrycia protonu, a kończąc na współczesnej radioterapii klinicznej. W 1990 rozpoczęła się nowoczesna era terapii wykorzystujących cząstki, kiedy został otwarty pierwszy specjalistyczny szpital leczący terapią protonową w Centrum Medycznym Uniwersytetu Loma Linda w Kalifornii. Od tamtej pory leczenie protonowe było przeprowadzane w placówkach szpitalnych używając technologii i technik, które były porównywalne z nowoczesną radioterapią fotonową. Dane kliniczne jednoznacznie potwierdzały, że terapia protonowa jest przodującą i lepszą metodą leczenia od konwencjonalnej radioterapii. W tym okresie pacjenci byli leczeni w kilku ośrodkach na świecie, gdzie metody i techniki napromieniania były różne, a nowe technologie były stale implementowane. Finalnie, dane kliniczne uzyskane w naukowych placówkach wykazały dobrą powtarzalność i wydajność terapii protonowej.
\end{abstract}

Słowa kluczowe: Terapia protonowa, historia, promieniowanie protonowe

\footnotetext{
Adres do korespondencji

Marika Musielak

Pracownia Radiobiologii,

Wielkopolskie Centrum Onkologii, ul. Garbary 15, 61-866 Poznań, Polska

Telefon. +48618850 474, +48505372 290

e-mail: marika.musielak@wco.pl
} 


\section{Wstęp}

Głównym celem radioterapii (ang. radiotherapy, RT) jest dostarczane promieniowania jonizującego do zmian nowotworowych. Napromienianie wykorzystuje się również w terapii paliatywnej oraz szeregu innych chorób nienowotworowych charakteryzujących się występowaniem bolesnych stanów zapalnych (1). Leczenie radioterapeutyczne obejmuje brachyterapię (implementacja źródła promieniowania w ciele pacjenta) oraz teleradioterapię (napromienianie pacjenta źródłem zewnętrznym). Do napromieniania wykorzystywane są przyspieszane $\mathrm{w}$ akceleratorach fotony, elektrony jak również protony i ciężkie jony (2). Wszystkie rodzaje promieniowania mają zastosowanie kliniczne, jednakże terapia protonowa (ang. proton therapy, PT) cieszy się stale rosnącą popularnością (3). RT jest standardowym sposobem leczenia w onkologii, gdzie ponad 50\% pacjentów jest traktowanych tego typu terapią w pewnym momencie leczenia $(4,5)$. Zazwyczaj RT stosuje się w połączeniu z chirurgią, chemioterapią i rzadziej, immunoterapią $(6,7)$. Podstawy stosowania promieniowania jonizującego bazują na transporcie energii do tkanek, skutkując zniszczeniami DNA oraz powstawaniem mutacji lub zmian prowadzących do upośledzenia fizjologii komórki nowotworowej i jej śmierci $(8,9)$. Determinowanie optymalnej modulacji promieniowania, wielkości dawki, strategii leczenia i kombinacji z innymi terapiami stało się aktywnym obszarem badań przez dekady (10-12). Postępy w fizyce, radiologii i radiobiologii pozwoliły działowi onkologii radiacyjnej na rozwój, skutkując bardziej korzystnymi klinicznie odpowiedziami jednocześnie minimalizując efekt toksyczności u zdrowych tkanek (13).

Podstawą PT jest wykorzystanie wiązki promieniowania protonowego. Opisując przewagę promieniowania protonowego nad konwencjonalnym fotonowym należy zwrócić uwagę na jego aspekty fizyczne m.in. rozkład głębokościowy dawki. Rozkład dawki w ośrodku maleje wykładniczo dla fotonów, natomiast dla protonów rozkład głębokości dawki ma charakterystyczny kształt, zwany pikiem Bragga (ryc.1) (14). W leczeniu klinicznym generuje się wiązki protonowe o energiach nominalnych rzędu od 70 do 250 megaelektronowoltów $(\mathrm{MeV})$, osiągając maksimum dawki na głębokości od $4 \mathrm{do} 37 \mathrm{~cm}$. Analizując ten sam aspekt dla promieniowania fotonowego obserwujemy maksimum dawki na poziomie 3-4 cm. Ta przewaga ma ogromne znaczenie dla leczenia guzów głęboko zlokalizowanych jak np. guzy wewnątrz czaszki. Charakterystycznym jest to, że dawka promieniowania protonowego za miejscem deponowania dawki maksymalnej praktycznie spada do zera. Dzięki temu możliwe jest podanie wysokiej dawki promieniowania do guza znacząco ograniczając ekspozycje na tkanki zdrowe, co jest kluczowym aspektem warunkującym dalszą jakość życia pacjenta. Podczas planowania terapii klinicyści spodziewają się zdecydowanie niższych skutków ubocznych oraz powikłań (15).

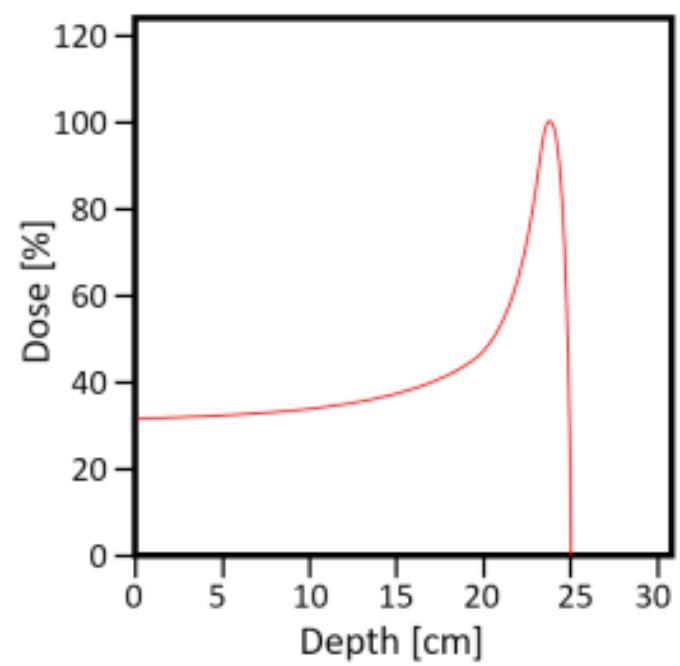

Ryc.1. Rozkład głębokościowy dawki dla wiązki protonowej (14)

Historia PT rozpoczęła się w 1946 roku kiedy Robert Wilson opublikował artykuł, w którym zaproponował wykorzystanie akceleratorów formujących wiązkę protonową do leczenia głęboko zlokalizowanych guzów (16). W tym artykule Wilson wyjaśnił biofizyczne podstawy dla PT, jak również kluczowe kwestie technik 
inżynieryjnych dostarczania wiązki. W 1954 napromieniono pierwszego pacjenta w Laboratorium Lawrence Berkeley (17,18). Kilka lat później, w 1962 Laboratorium Cyklotronowe Harwardu było znane z leczenia radiochirurgicznego z użyciem protonów (19). 10 lat później rozpoczęły się procedury leczenia nowotworów oka i większych guzów (20). Tamtejsi fizycy współpracowali z klinicystami ze Szpitala Generalnego w Massachusetts, dzięki czemu rozwinęli fizyczne i technologiczne aspekty potrzebne do leczenia pacjentów w sposób bezpieczny i efektywny. Wartym uwagi jest fakt, że program na Harwardzie był kontynuowany przez ponad 40 kolejnych lat. W tym czasie, naukowcy na świecie pracowali nad modernizacją i większą efektywnością PT skupiając się na budowie akceleratorów, wiązkach skanujących, systemach planowania leczenia (21).

\section{Historia protonu}

Odkrycie promieniowania rentgenowskiego przez Wilhelma Roentgena w późnych latach XIX wieku sprawiło, że dział fizyki radiacyjnej doświadczył znaczącego rozwoju (ryc.2). Podczas tego okresu Ernest Rutherford zidentyfikował cząstki alfa w promieniowaniu emitowanym przez sole uranowe (22). Jednocześnie Geiger i Marsden zaobserwowali, że cząstki alfa odchylają się pod kątem większym niż $90^{\circ}$ bombardując cienką złotą folię (23). Siedem lat później Rutherford doszedł do wniosku, że istnieje nowa, niezidentyfikowana struktura atomowa, która mogłaby wyjaśnić te odchylenia. Fizyk określił ją „protonem” oraz składową jądra atomowego. To doprowadziło do powszechnie znanego „Eksperymentu rozproszenia Rutherforda”, które zapoczątkowało odkrycie jądra atomowego w 1911 (24). W ciągu roku Rutherford opublikował nowy model atomu pokazujący, że atom składa się z elektronów orbitujących wokół bardzo małego jądra, które koncentruje większość masy atomu oraz ładunku. Dzięki swoim odkryciom Rutherford został nazwany ojcem protonu. Nazwa „proton” pochodzi od greckiego słowa „protos”, które oznacza pierwotny lub podstawowy (25). W 1910 roku protony były uważane za najbardziej podstawowe cząstki. Aktualnie wiadome jest, że cząsteczka atomu składa się z bardziej fundamentalnych komponentów nazywanych kwarkami (26).

W 1924 roku został opublikowany opis Gustava Ising’a o podstawach liniowych akceleratorów (27). Od tamtego czasu wiele typów akceleratorów było rozwijanych, aby służyć w laboratoriach wysokoenergetycznej fizyki nuklearnej. W 1930 Robert J. Van de Graaff zaprojektował elektrostatyczny generator do indukcji bardzo wysokich woltaży (28). Było to wykorzystywane do przyspieszania naładowanych cząstek jak elektrony, jednakże nie było to wystarczające do generowania wysokich wartości. Dwóch fizyków, Ernest Lawrence i Stanley Livingstone, wynaleźli cyklotron w 1931, który z sukcesem przyspieszał jony rtęci do $80 \mathrm{keV}$ (29). W 1932 John D. Cockroft i Ernest T.S. Walton skonstruowali mechanizm generujący wysokie

\section{HISTORIA TERAPII PROTONOWEJ}

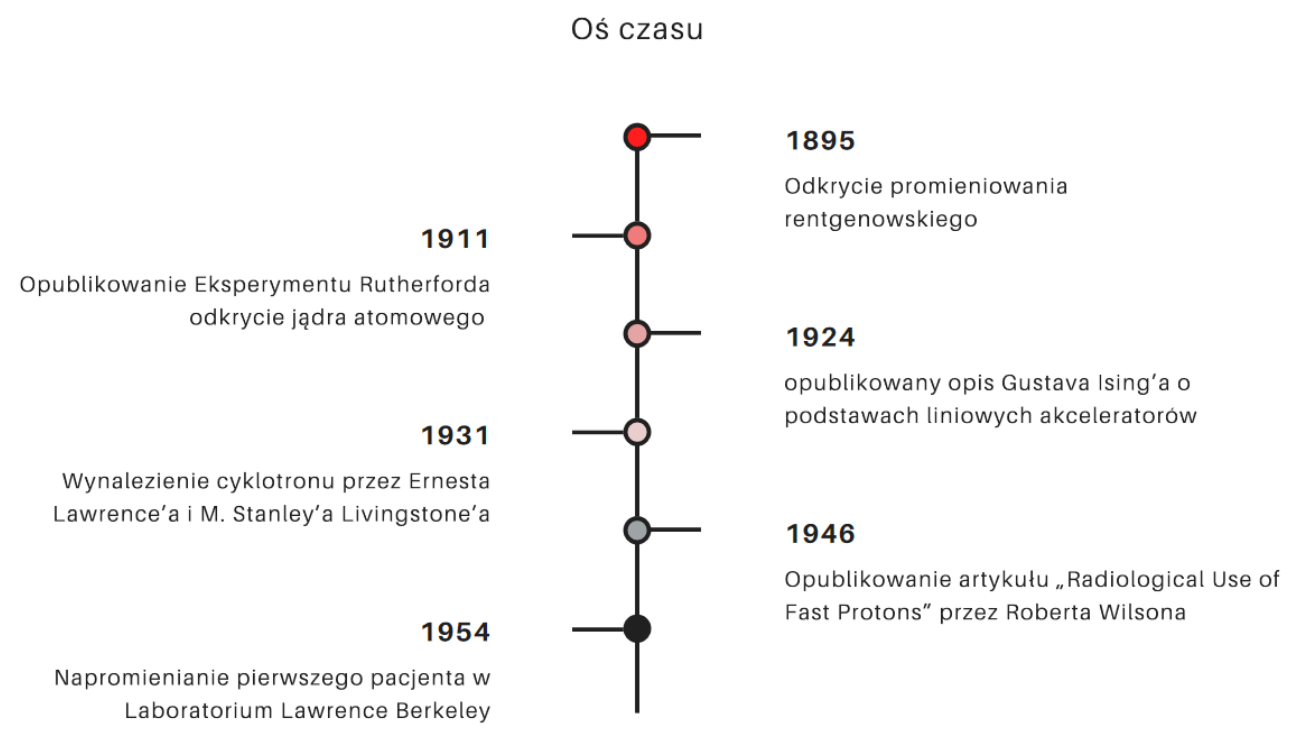

Ryc.2. Historia terapii protonowej. Oś czasu przestawiająca najważniejsze wydarzenia związane z powstaniem terapii protonowej na świecie 
energie finalnie doprowadzając do skonstruowania pierwszego akceleratora Cockrofta i Waltona (30). Był on zdolny do przyspieszenia protonów nawet do $700 \mathrm{keV}$. Za pomocą akceleratora naukowcy przeprowadzili pierwszą reakcję jądrową oraz pierwsze rozdzielnie atomu wykorzystując wyindukowane protony. Była to pierwsza sformułowana wiązka protonowa.

\section{Wiązka protonowa $\mathrm{w}$ radioterapii}

W 1946 roku, 27 lat po odkryciu protonu, Robert R Wilson zaproponował, aby protony mogły być terapeutycznie wykorzystane w medycynie. Artykuł „Radiological Use of Fast Protons” został opublikowany, aby poinformować medyków i biologów o szczegółowej kalkulacji odnośnie fizycznych właściwości i możliwego terapeutycznego zastosowania protonów, deuteronów, i cząstek alfa (16). To Wilson przedstawił terapię wiązką cząstek i do dzisiaj jest znany jako ojciec PT. Zaprojektował on urządzenia wykorzystujące promieniowanie, których głównym celem było napromienienie zmian nowotworowych, nie powodując jednocześnie uszkodzeń tkanek zdrowych. Dziękijego pracy uzyskano wiedzęo możliwościach przyspieszania protonów i formowania z nich wiązki promieniowania o wysokiej intensywności. W latach 1967-1978, Wilson był pierwszym dyrektorem Narodowego Laboratorium Przyśpieszania Cząstek Elementarnych im. Enrico Fermiego w Chicago, Illinois w Stanach Zjednoczonych (31).

Konstrukcja pierwszego na świecie cyklotronu została ukończona w 1931 przez amerykańskiego fizyka Ernesta Orlando Lawrence’a (17). Po udoskonaleniu rozmiarów i mocy cyklotronu, konstrukcja, która była w stanie wygenerować protony o energii $340 \mathrm{MeV}$ została ukończona w Berkeley w 1947 (32). Dzięki tej aparaturze naukowcy mogli przeprowadzić badania, które doprowadziły do odkrycia wielu nowych zjawisk oraz procesów fizycznych, ale również do wprowadzenia medycznych innowacji, w tym RT i generowania radioizotopów. Ponadto, wiązki protonowe zaczęto analizować pod kątem biologicznej efektywności przeprowadzając testy na zwierzętach.

W tym czasie Laboratorium promieniowania w Berkeley odgrywało ważną rolę na arenie międzynarodowej i prowadziło szerokie badania na protonach, udowadniając ideę Wilsona. Były to zazwyczaj eksperymenty prowadzone przez Davida Herberta Lawrence’a, który był bratem Ernesta (33,34). Pierwsze serie eksperymentów na zwierzętach były przeprowadzane na przysadkach mózgowych szczurów (35), a następnie przysadkach mózgowych małp (36). Pierwszym zwierzęciem, które było leczone PT był pies z rakiem piersi. Przysadka psa została usunięta radiochirurgicznie wykorzystując wiązkę protonową. Zwierzę przeżyło kolejne dwa lata po leczeniu (34).

Inspirując się wynikami raportowanymi w Berkeley, zainicjowano w 1954 biomedyczny program Uniwersytetu w Uppsali w Szwecji. Wykorzystano tam $185 \mathrm{MeV}$ wiązki protonowe pod kierownictwem B. Larssona (37). Po szerokich badanach radiobiologicznych w latach 1957-1968, zespół zaobserwował, że biologiczna skuteczność $185 \mathrm{MeV}$ protonów jest ekwiwalentem promieni gamma ${ }^{60} \mathrm{CO}$ (38). Zainicjowali także serie radiochirurgicznych eksperymentów wykorzystując wiązkę protonową na mózgu i rdzeniu kręgowym królików i kóz (39-41). Paganetti H et al. (42) zestawili wartości względnej skuteczności biologicznej (WSB) w badaniach in vitro i in vivo. Analizy eksperymentów in vivo oraz danych klinicznych wyznaczyły kontynuowanie ustalania ogólnej wartości WSB. W raporcie Międzynarodowej Komisji Jednostek Radiologicznych Międzynarodowej Agencji Energii Atomowej zarekomendowano WSB dla protonów o wartości 1.1 dla klinicznych zastosowań (43).

\section{Terapia protonowa na świecie}

Instytut Gustava Wernera w Uppsali w Szwecji był pierwszym, który zastosował idee piku Bragga i jednocześnie koncept zaproponowany przez Robert Wilsona w badaniach PT. W późnych latach 50. do wczesnych 6o. wykorzystano cyklotron $185 \mathrm{MeV}$ do leczenia pierwszej grupy pacjentów. Jednocześnie skupiono się nad radiochirurgią stereotaktyczną za kierownictwem pioniera w tej dziedzinie Larsa Leksella $(41,44)$. W tym celu wygenerowano wiązkę o modulowanym zakresie z rozszerzonym pikiem Bragga za pomocą techniki rotującej $(38,45)$. Równolegle wykorzystywano protony jako neurochirurgiczne narzędzie do operacji mózgu (39). W Uppsali leczono również pacjentki ze złośliwym nowotworem piersi napromieniając wiązką protonów gruczoł przysadki $(44,46)$. Zespół rozwinął też technologię frakcjonowanej PT z wykorzystaniem dużych 
pól napromieniania lecząc guzy rozszerzonym pikiem Bragga. Zademonstrowali, że każda objętość w ciele pacjenta może zostać selektywnie napromieniona protonami (47).

W 1960 roku we współpracy z Generalnym Szpitalem w Massachusetts, Laboratorium Cyklotronu na Harwardzie wypuściło program wykorzystując $160 \mathrm{MeV}$ cyklotron, który również generował dystrybucję dawki w postaci piku Bragga (48). Ponownie skupiono się na guzach neurologicznych skierowanych na leczenie radiochirurgiczne $\mathrm{z}$ naciskiem na przysadkę. Pacjentom $\mathrm{z}$ takimi schorzeniami jak akromegalia i choroba Cushinga umieszczano czaszkę w ramie głowy aby wycelować w „punt wiązki” w obrębie siodła tureckiego. Autorzy pod kierownictwem Kjellberg'a uzyskali satysfakcjonujące rezultaty, a w tym znaczącą redukcję efektów ubocznych. Ich sukces osiągnął szerokie uznanie, dzięki czemu otrzymali finansowanie agencji takich jak Narodowy Instytut Onkologii (49).

We wczesnych latach 1970, Departament Onkologii Radiacyjnej Szpitala Generalnego w Massachusetts poszerzyła leczenie PT o pacjentów z mięsakami, nowotworami głowy i szyi oraz zmianami skórnymi (50-52). W 1979, kolejną grupą leczoną protonami byli pacjenci z nowotworem prostaty (53). Za pomocą PT leczono 17 mężczyzn ze zlokalizowanym guzem prostaty. Kontrolowana obserwacja pacjentów trwała od 12 do 17 miesięcy. Zarejestrowane efekty uboczne były łagodne odnotowując występowanie minimalnych odczynów w obszarze odbytnicy. W tym samym szpitalu dyrektor departamentu neurochirurgii był zainteresowany leczeniem wiązką protonową i dołączył do zespołu Kjellberg’a, aby wykorzystać protony do leczenia obszarów mózgu. Grupa również skupiła się na leczeniu przysadki mózgu i głębiej osadzonych guzów (48).

Inni badacze pod zwierzchnictwem Lawrence'a zaraportowali imponujące rezultaty radiochirurgii przysadki u 26 pacjentek z rakiem piersi wykonując protonową hipofizektomię. Twierdzono, że ten typ leczenia będzie w stanie upośledzić funkcje przysadki, która wydzielając hormony powodowała dalszy rozwój nowotworu piersi. Zaobserwowano poprawę stanu zdrowia u kilku pacjentów $(18,34)$. Później, wraz z rozwojem tomografii komputerowej i zaawansowaniem leczenia przysadki wykorzystując mikroskopy, hipofizektomia protonami została wstrzymana. W 1970 roku Kjellberg zmienił swój cel i skoncentrował się na leczeniu malformacji tętniczo-żylnej w mózgu i podstawie czaszki. Wykorzystywał pasywny system dostarczania wiązki promieniowania ponieważ nie znano wtedy żadnego efektywnego sposobu leczenia tych obszarów (47).

W latach 70. Rosja zainicjowała kilka programów stosowania PT. Realizacja obejmowała kilka instytucji jak Zjednoczony Instytut Badań Jądrowych i Główny Instytut Badań Rentgenowskich i Radiologicznych (54). Do 1981, wyleczono około 600 pacjentów z rakiem piersi oraz prostaty z przerzutami do kości, węzłów chłonnych, jak i pacjentów cierpiących na osteosarcomę, melanomę, nowotwory szyi i oczu (55). W Japonii w 1979 otwarto Narodowy Instytut Nauk Radiologicznych w Chibie, którego część obejmowała urządzenia związane z PT skupiając się na leczeniu okulistycznych i powierzchniowych guzów (56)Chiba, and the Particle Radiation Medical Science Center (PARMS. Instytut był również pionierem w kwestii rozwoju trójwymiarowej techniki skanowania, aby zredukować dawkę poza napromienianą objętością (57). Kolejnym miejscem rozwoju PT było Centrum Badań Terapii Cząsteczkowej na Uniwersytecie Sukuby gdzie rozpoczęto badania podstawowe i kliniczne w celu leczenia guzów w głęboko zlokalizowanych organach z wykorzystaniem wysokoenergetycznych protonów generowanych przez synchrotrony Instytutu Fizyki Wysokich Energii w 1983 (56)Chiba, and the Particle Radiation Medical Science Center (PARMS. Warto zauważyć, że zajmowano się tam leczeniem najczęściej występujących nowotworów jak rak płuc, wątroby, macicy i jajników. Co więcej, grupa również rozwinęła system bramkowania uzależniony od ruchów oddechowych pacjenta do leczenia poruszającego się guza w płucach pacjenta (58). Drugie Światowe centrum terapii protonowej dedykowane wykorzystaniu medycznemu zostało wybudowane w Narodowym Centrum Onkologii Wschodu w Japonii w 1997, 7 lat po otwarciu centrum w Uniwersytecie Loma Linda. Od tego czasu liczba instytucji PT znacząco rosła. Aktualnie na świecie jest 109 placówek leczących za pomocą PT, z których 37 jest zlokalizowanych w Stanach Zjednoczonych bazując na informacjach zawartych na The Particle Therapy Co-Operative Group z sierpnia 2020.

\section{Wnioski}

W 1970 PT zaczęła być wykorzystywana w placówkach naukowych w celu leczenia pacjentów onkologicznych za pomocą frakcjonowanego leczenia. Od 1990 leczenie protonowe było przeprowadzane 
w placówkach szpitalnych używając technologii i technik, które były porównywalne z nowoczesną RT fotonową. Dane kliniczne jednoznacznie potwierdzały, że PT jest przodującą i lepszą od konwencjonalnej RT. Zoptymalizowana dystrybucja dawki protonów może zostać osiągnięta z PT o modulowanej intensywności dawki (ang. intensity modulated proton therapy, IMPT), jednakże niewielu pacjentów ma szansę otrzymać tego rodzaju leczenie. Oczekuje się, że szeroka implementacja IMPT dostarczy dodatkowej poprawy w leczeniu klinicznym (59).

Techniczne wyzwanie stanowi możliwość przyspieszania cząstek do bardzo wysokich energii wymaganych do osiągnięcia docelowych głębokości w ciele pacjenta. Rozwój PT był związany z rozwojem cyklotronów i synchrotronów oraz akceleratorów, których pierwotnym przeznaczeniem były badanie naukowe poświęcone fundamentalnej fizyce jądrowej (6o). Od kiedy pierwszy pacjent został napromieniony, postęp w dziedzinie PT był raczej niewielki w ciągu kolejnych 35 lat. W tym okresie pacjenci byli leczeni w kilku ośrodkach na świecie, gdzie metody i techniki PT były różne, a nowe technologie były stale implementowane. Finalnie, dane kliniczne uzyskane w naukowych placówkach wykazały dobrą powtarzalność i wydajność PT. W 1990 rozpoczęła się nowoczesna era terapii wykorzystujących cząstki, kiedy został otwarty pierwszy specjalistyczny szpital leczący PT w Centrum Medycznym Uniwersytetu Loma Linda w Kalifornii.

Problematyczną kwestią w PT jest to, że na wygenerowanie użytecznych informacji z randomizowanych badań klinicznych potrzeba od 15 do 20 lat, co jest nierealistyczne, ponieważ radioterapia jest szybko rozwijająca się dziedziną. Obserwacja lub porównanie technik nie będzie możliwe z powodu zmiany kryteriów i pojawienia się nowych strategii lub rozwiązań technologicznych. Dlatego obserwowane na przestrzeni ostatnich lat efekty i wyciągane z nich wnioski nie mogą być użyteczne i stosowane w przyszłości. Należy jednak podkreślić, że wyniki osiągnięte w starszych badaniach nad PT przyczyniły się do jej dalszego stosowania stanowiąc podstawę praktyki klinicznej i jej dalszego udoskonalania. Aktualnie prowadzonych jest wiele badań nad PT, aby leczenie było coraz bardziej personalizowane i mogło maksymalnie zmniejszyć nasilenie skutków ubocznych u pacjentów.

\section{Bibliografia}

[1] Vakaet LAM-L, Boterberg T. Pain control by ionizing radiation of bone metastasis. Int J Dev Biol. 2004;48(5-6):599-606.

[2] Podgoršak EB, International Atomic Energy Agency, editors. Radiation oncology physics: a handbook for teachers and students. Vienna: International Atomic Energy Agency; 2005. 657 p.

[3] Studenski MT. Proton therapy dosimetry using positron emission tomography. World J Radiol. 2010;2(4):135.

[4] Barton MB, Frommer M, Shafiq J. Role of radiotherapy in cancer control in low-income and middleincome countries. Lancet Oncol. $2006 \mathrm{Jul} ; 7(7): 584-95$.

[5] Barton MB, Jacob S, Shafiq J, Wong K, Thompson SR, Hanna TP, et al. Estimating the demand for radiotherapy from the evidence: A review of changes from 2003 to 2012. Radiother Oncol. 2014 Jul;112(1):140-4.

[6] Lichter AS, Lawrence TS. Recent Advances in Radiation Oncology. N Engl J Med. 1995 Feb 9;332(6):3719.

[7] Tang C, Wang X, Soh H, Seyedin S, Cortez MA, Krishnan S, et al. Combining Radiation and Immunotherapy: A New Systemic Therapy for Solid Tumors? Cancer Immunol Res. 2014 Sep;2(9):8318.

[8] Roos WP, Kaina B. DNA damage-induced cell death: From specific DNA lesions to the DNA damage response and apoptosis. Cancer Lett. 2013 May;332(2):237-48.

[9] Jackson SP, Bartek J. The DNA-damage response in human biology and disease. Nature. 2009 Oct;461(7267):1071-8.

[10] Ellis F. Dose, time and fractionation: A clinical hypothesis. Clin Radiol. 1969 Jan;20(1):1-7.

[11] Begg AC, Stewart FA, Vens C. Strategies to improve radiotherapy with targeted drugs. Nat Rev Cancer. 2011 Apr;11(4):239-53.

[12] Musielak M. Ocena wpływu dawki i mocy promieniowania jonizującego na komórki raka piersi. The 
assessment of the effect of ionizing radiation dose and dose rate for breast cancer cells. Lett Oncol Sci. 2019 Jan 7;15(4):117-25.

[13] Bernier J, Hall EJ, Giaccia A. Radiation oncology: a century of achievements. Nat Rev Cancer. 2004 Sep;4(9):737-47.

[14] Musielak M, Suchorska WM, Fundowicz M, Milecki P, Malicki J. Future Perspectives of Proton Therapy in Minimizing the Toxicity of Breast Cancer Radiotherapy. J Pers Med. 2021 May 13;11(5):410.

[15] Planowanie leczenia i dozymetria w radioterapii (Tom 2) - Julian Malicki, Krzysztof Ślosarek, Via Medica [Internet]. [cited 2020 Apr 16]. Available from: https://medbook.com.pl/ksiazka/pokaz/id/16064/tytul/ planowanie-leczenia-i-dozymetria-w-radioterapii-tom-2-malicki-slosarek-via-medica

[16] Wilson RR. Radiological Use of Fast Protons. Radiology. 1946 Nov;47(5):487-91.

[17] Lawrence EO, Livingston MS. The Production of High Speed Light Ions Without the Use of High Voltages. Phys Rev. 1932 Apr 1;40(1):19-35.

[18] Lawrence JH. Proton irradiation of the pituitary. Cancer. 1957 Jul;10(4):795-8.

[19] Munzenrider JE, Austin-Seymour M, Blitzer PJ, Gentry R, Goitein M, Gragoudas ES, et al. Proton therapy at Harvard. Strahlentherapie. 1985 Dec;161(12):756-63.

[20] Verhey LJ. [No title found]. Int J Radiat Oncol. 2005 Mar;61(4):1280.

[21] Newhauser WD, Zhang R. The physics of proton therapy. Phys Med Biol. 2015 Apr 21;60(8):R155-209.

[22] L'Annunziata MF. Radioactivity: introduction and history, from the Quantum to Quarks. Second edition. Amsterdam ; Boston: Elsevier; 2016. 902 p.

[23] On a diffuse reflection of the $\alpha$-particles. Proc R Soc Lond Ser Contain Pap Math Phys Character. 1909 Jul 31;82(557):495-500.

[24] Rutherford E. LIV. Collision of a particles with light atoms . IV. An anomalous effect in nitrogen. Lond Edinb Dublin Philos Mag J Sci. 1919 Jun;37(222):581-7.

[25] Romer A. Proton or prouton?: Rutherford and the depths of the atom. Am J Phys. 1997 Aug;65(8):707-16.

[26] Yasuoka K. Discovery of the Proton and Its Intrinsic Powers. In: Tsuboi K, Sakae T, Gerelchuluun A, editors. Proton Beam Radiotherapy [Internet]. Singapore: Springer Singapore; 2020 [cited 2021 Nov 2]. p. 3-8. Available from: http://link.springer.com/10.1007/978-981-13-7454-8_1

[27] Sessler A, Wilson E. Engines of Discovery: A Century of Particle Accelerators Revised and Expanded Edition [Internet]. WORLD SCIENTIFIC; 2014 [cited 2021 Nov 6]. Available from: http://www. worldscientific.com/worldscibooks/10.1142/8552

[28] Burrill EA. Van de Graaff, the man and his accelerators. Phys Today. 1967 Feb;20(2):49-52.

[29] Courant ED, Livingston MS, Snyder HS. The Strong-Focusing Synchroton-A New High Energy Accelerator. Phys Rev. 1952 Dec 1;88(5):1190-6.

[30] The Atomic Energy Research Establishment, Harwell. Nature. 1948 Aug;162(4113):317-20.

[31] L. Elaimy A, Ding L, Bradford C, Geng Y, Bushe H, Kuo I-L, et al. History and Overview of Proton Therapy. In: J. FitzGerald T, Bishop-Jodoin M, editors. Proton Therapy - Current Status and Future Directions [Internet]. IntechOpen; 2021 [cited 2021 Nov 6]. Available from: https://www.intechopen. com/books/proton-therapy-current-status-and-future-directions/history-and-overview-of-protontherapy

[32] Lawrence EO, Alvarez LW, Brobeck WM, Cooksey D, Corson DR, McMillan EM, et al. Initial Performance of the 6o-Inch Cyclotron of the William H. Crocker Radiation Laboratory, University of California. Phys Rev. 1939 Jul 1;56(1):124-124.

[33] Tobias CA, Anger HO, Lawrence JH. Radiological use of high energy deuterons and alpha particles. Am J Roentgenol Radium Ther Nucl Med. 1952 Jan;67(1):1-27.

[34] Lawrence JH, Tobias CA, Born JL, McCOMBS RK, Roberts JE, Anger HO, et al. Pituitary irradiation with high-energy proton beams: a preliminary report. Cancer Res. 1958 Feb;18(2):121-34.

[35] Larsson B, Larsson B. Radiological Properties of Beams of High-Energy Protons. Radiat Res Suppl. 1967;7:304.

[36] Simpson ME, Van Wagenen G, Van Dyke DC, Koneff AA, Tobias CA. DEUTERON IRRADIATION OF THE MONKEY PITUITARY ${ }^{1}$. Endocrinology. 1959 Nov;65(5):831-57.

[37] Professor Börje Larsson, 1931-1998: A Multidisciplinary Scientist. Acta Oncol. 1999 Jan;38(3):389-90.

[38] Falkmer S, Fors B, Larsson B, Lindell A, Naeslund J, Stenson S. Pilot Study on Proton Irradiation of 
Human Carcinoma. Acta Radiol. 1962 Feb 1;Original Series, Volume 58(1):33-51.

[39] Larsson B, Leksell L, Rexed B, Sourander P, Mair W, Andersson B. The High-Energy Proton Beam as a Neurosurgical Tool. Nature. 1958 Nov;182(4644):1222-3.

[40] Larsson B, Leksell L, Rexed B, Sourander P. Effect of high energy protons on the spinal cord. Acta Radiol. 1959 Jan;51(1):52-64.

[41] Leksell L, Larsson B, Andersson B, Rexed B, Sourander P, Mair W. Lesions in the Depth of the Brain Produced by a Beam of High Energy Protons. Acta Radiol. 1960 Oct;54(4):251-64.

[42] Paganetti H, Niemierko A, Ancukiewicz M, Gerweck LE, Goitein M, Loeffler JS, et al. Relative biological effectiveness (RBE) values for proton beam therapy. Int J Radiat Oncol. 2002 Jun;53(2):407-21.

[43] Internationale Atomenergie-Organisation, International Commission on Radiation Units and Measurements, editors. Relative biological effectiveness in Ion Beam Therapy. Vienna: International Atomic Energy Agency; 2008. 153 p. (Technical reports series / International Atomic Energy Agency).

[44] Larsson B. Pre-therapeutic Physical Experiments with High Energy Protons. Br J Radiol. 1961 Mar;34(399):143-51.

[45] Fors B, Larsson B, Lindell A, Naeslund J, Sténson S. Effect of High Energy Protons on Human Genital Carcinoma. Acta Radiol Ther Phys Biol. 1964 Jan;2(5):384-98.

[46] Graffman S, Brahme A, Larsson B. Proton radiotherapy with the Uppsala cyclotron. Experience and plans. Strahlentherapie. 1985 Dec;161(12):764-70.

[47] Kjellberg RN, Hanamura T, Davis KR, Lyons SL, Adams RD. Bragg-Peak Proton-Beam Therapy for Arteriovenous Malformations of the Brain. N Engl J Med. 1983 Aug 4;309(5):269-74.

[48] Kjellberg RN, Sweet WH, Preston WM, Koehler AM. The Bragg peak of a proton beam in intracranial therapy of tumors. Trans Am Neurol Assoc. 1962;87:216-8.

[49] Kjellberg RN, Kliman B. Bragg peak proton treatment for pituitary-related conditions. Proc R Soc Med. 1974 Jan;67(1):32-3.

[50] Robertson JB, Williams JR, Schmidt RA, Little JB, Flynn DF, Suit HD. Radiobiological studies of a highenergy modulated proton beam utilizing cultured mammalian cells. Cancer. 1975 Jun;35(6):1664-77.

[51] Suit HD, Goitein M, Tepper J, Koehler AM, Schmidt RA, Schneider R. Exploratory study of proton radiation therapy using large field techniques and fractionated dose schedules. Cancer. 1975 Jun;35(6):1646-57.

[52] Gragoudas ES, Goitein M, Koehler AM, Verhey L, Tepper J, Suit HD, et al. Proton Irradiation of Small Choroidal Malignant Melanomas. Am J Ophthalmol. 1977 May;83(5):665-73.

[53] Shipley WU, Tepper JE, Prout GR, Verhey LJ, Mendiondo OA, Goitein M, et al. Proton radiation as boost therapy for localized prostatic carcinoma. JAMA. 1979 May 4;241(18):1912-5.

[54] Chuvilo IV, Goldin LL, Khoroshkov VS, Blokhin SE, Breyev VM, Vorontsov IA, et al. ITEP synchrotron proton beam in radiotherapy. Int J Radiat Oncol. 1984 Feb;10(2):185-95.

[55] Savinskaia AP, Minakova EI. [Proton hypophysectomy and the induction of mammary cancer]. Med Radiol (Mosk). 1979 Feb;24(2):53-7.

[56] Tsunemoto H, Morita S, Ishikawa T, Furukawa S, Kawachi K, Kanai T, et al. Proton therapy in Japan. Radiat Res Suppl. 1985;8:S235-243.

[57] Kanai T, Kawachi K, Kumamoto Y, Ogawa H, Yamada T, Matsuzawa H, et al. Spot scanning system for proton radiotherapy. Med Phys. 1980 Jul;7(4):365-9.

[58] Ohara K, Okumura T, Akisada M, Inada T, Mori T, Yokota H, et al. Irradiation synchronized with respiration gate. Int J Radiat Oncol. 1989 Oct;17(4):853-7.

[59] Ju M, Berman AT, Vapiwala N. The Evolution of Proton Beam Therapy: Insights From Early Trials and Tribulations. Int J Radiat Oncol. 2014 Nov;90(4):733-5.

[6o] Joiner M, Kogel A van der, editors. Basic clinical radiobiology. Fifth edition. Boca Raton, FL: CRC Press/ Taylor \& Francis Group; 2018. 